\title{
Past SARS-CoV-2 infection elicits a strong immune response after a single vaccine dose
}

One-Sentence Summary: First vaccine dose in subjects with prior COVID19 elicits a higher antibody response than two doses in uninfected individuals del Mar Vélez ${ }^{4}$, Agustín Stagnetto ${ }^{2}$, César Luís Ávila² ${ }^{2}$ Carolina Maldonado-Galdeano ${ }^{3}$, Sergio Benjamín Socias ${ }^{2}$, Dar Heinze ${ }^{5}$, Silvia Adriana Navarro ${ }^{2}$, Conrado Llapur ${ }^{4}$, Dardo Costas ${ }^{4}$, Isolina Flores ${ }^{4}$, Gabriela Apfelbaum ${ }^{6}$, Raúl Mostoslavsky ${ }^{7}$, Gustavo Mostoslavsky ${ }^{5}$, Gabriela Perdigón $^{3 *}$, Rosana Nieves Chehín ${ }^{2} *$

\section{Affiliations:}

\author{
${ }^{1}$ Tucumán Public Healthcare Administration (SIPROSA) \\ ${ }^{2}$ Instituto de Medicina Molecular y Celular Aplicada - IMMCA (UNT-CONICET-SIPROSA). \\ Tucumán Argentina
}

${ }^{3}$ Centro de Referencia para Lactobacilos - CERELA (CONICET). Tucumán, Argentina

${ }^{4}$ Néstor Kirchner Hospital, Central Public Health laboratory (LSP) (SIPROSA). Tucumán, Argentina.

${ }^{5}$ Section of Gastroenterology, Department of Medicine, Center for Regenerative Medicine (CReM), Boston University School of Medicine, Boston, USA

${ }^{6}$ School of Medicine - Universidad Nacional de Tucumán. Tucumán, Argentina

${ }^{7}$ The Massachusetts General Hospital Cancer Center, Harvard Medical School, Boston, USA

${ }^{\dagger}$ These authors contributed equally to this work

*Corresponding authors. Email: rosanachehin@ gmail.com; perdigon@ cerela.org.ar 
medRxiv preprint doi: https://doi.org/10.1101/2021.03.14.21253039; this version posted March 24, 2021. The copyright holder for this preprint (which was not certified by peer review) is the author/funder, who has granted medRxiv a license to display the preprint in perpetuity.

All rights reserved. No reuse allowed without permission.

Abstract: We hypothesized that in individuals with previous SARS-CoV-2 infection, the first vaccine dose would work as a booster, eliciting a faster and more intense immune response. We herein describe antibody responses to the first and second doses of Gam-COVID-Vac (SPUTNIK V) vaccine in health personnel of Tucumán, Argentina, with previous COVID-19 and compared it with uninfected personnel. Individuals with anti-SARS-CoV-2 titers at baseline showed significantly higher responses to the first dose than people with no prior history of disease ( $\mathrm{p}<0.0001$ ), with titers higher to those registered after the second dose in the control group, representing a clear secondary antibody response. This suggests that a single dose of SPUTNIK V for people with previous SARS-CoV-2 infection could contribute to a better use of available doses.

\section{Main Text}

The need to control the transmissibility and mortality associated with SARS-CoV-2 has transformed vaccines into a critical resource to mitigate the devastating effects of the pandemic originated in Wuham in December 2019 (1, 2). The appearance of new virus variants (3), whose selective pressure depends on the transmission of the virus, reinforces the need to accelerate the vaccination process in all countries (4). However, despite the unprecedented speed of development of different vaccines around the world, their availability remains very limited. This situation is even more critical in underdeveloped or developing countries. In Argentina, the local regulatory authority has so far approved two adenovirus-based vaccines, Gam-COVID-Vac (SPUTNIK V) and Oxford-AstraZeneca, which rely on a prime-booster approach. 
medRxiv preprint doi: https://doi.org/10.1101/2021.03.14.21253039; this version posted March 24, 2021. The copyright holder for this preprint (which was not certified by peer review) is the author/funder, who has granted medRxiv a license to display the preprint in perpetuity.

All rights reserved. No reuse allowed without permission.

The persistence of humoral and cellular immunity against SARS-CoV-2 in convalescent patients has generated new questions regarding the requirement for a two-dose regimen in both adenovirus-based and mRNA vaccines (5-7). In this context, this work aimed at studying the post-vaccination humoral immune response to SPUTNIK V in a population of individuals with previous SARS-CoV-2 seroconversion and comparing it with a control group with no previous history of disease.

The immune response to the SPUTNIK V vaccine (rAd26 and rAd5) was analyzed in volunteer healthcare personnel (HCP) who were vaccinated between December 2020 and February 2021 in Tucumán-Argentina. A highly specific and sensitive anti-RBD IgG ELISA test (MEDRXIV/2021/252711, see Methods) was used to study the general response of the HCP population to immunization with SPUTNIK V, following the scheme provided by the Argentinean Ministry of Health. This test detects antibodies raised against the receptor binding domain (RBD) of the Spike (S) protein of SARS-CoV-2, and its correlation with virus neutralization has been well documented $(8,9)$. Before vaccination, basal IgG anti-RBD titers were measured in $602 \mathrm{HCP}$ volunteers. Antibody titers, calculated as the dilution in which the optical density (OD) obtained was equal to the lowest detectable value that indicates a positive result (see Methods), were detected in $45.2 \%$ of volunteers (Fig. 1A, solid and spotted purple), despite the fact that only $21 \%$ had confirmed previous natural infection as informed by the public health system (by RT-PCR or rapid antigen test). We consider this population with anti-RBD antibodies at baseline the seropositive group for the purpose of this study. After vaccination with SPUTNIK V, anti-RBD antibody titers were measured at i) 0 days post vaccination (dpv), ii) $14 \mathrm{dpv}$ and iii) $28 \mathrm{dpv}$ (7 days after the second dose), in 252, 520 and 374 samples respectively. At the beginning of the vaccination scheme (0 dpv), the mean IgG anti-RBD titer was 210. After the first dose of SPUTNIK V (14 dpv), the 
medRxiv preprint doi: https://doi.org/10.1101/2021.03.14.21253039; this version posted March 24, 2021. The copyright holder for this preprint (which was not certified by peer review) is the author/funder, who has granted medRxiv a license to display the preprint in perpetuity.

All rights reserved. No reuse allowed without permission.

mean titer reached 753 , while at $28 \mathrm{dpv}$, the mean titer rose to 1771 , with $97.05 \%$ of individuals showing seropositivity (Fig. 1B). A small but statistically significant difference was observed between antibody titers elicited $28 \mathrm{dpv}$ between male and female HCP (Fig. 1C). When subjects were grouped according to age (between 21-60 years of age), no statistical difference was found between mean antibody titers elicited by each age group (Fig. 1D).

A

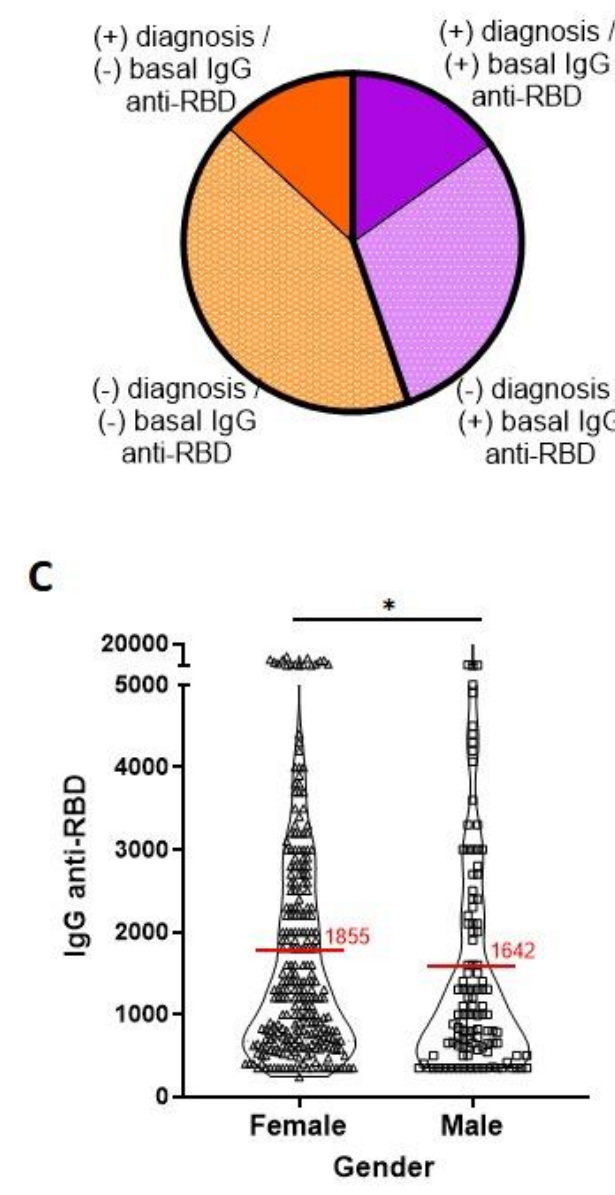

B

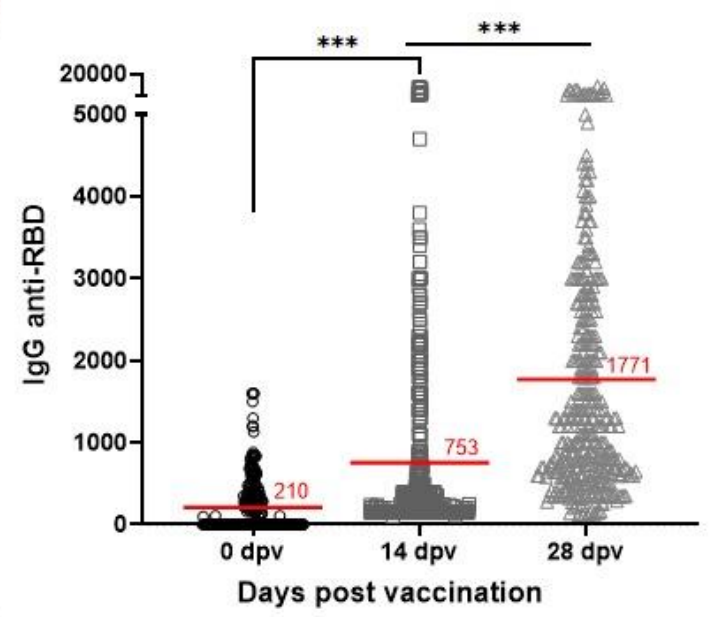

D

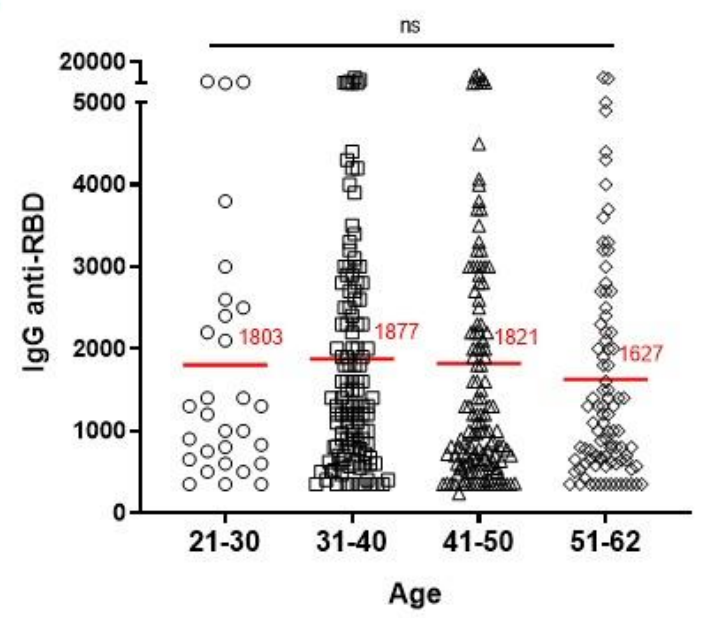

Figure 1. Humoral immune response elicited in 602 individuals after receiving the

SPUTNIK V vaccine. (A) Distribution of vaccinated population according to the presence of basal IgG anti-RBD and the history of previous documented COVID-19 diagnosis. (B) AntiRBD specific titers, as measured by ELISA, at 0 days post-vaccination (dpv) (black circles), 14 $\mathrm{dpv}$ (dark grey squares) and $28 \mathrm{dpv}$ (light grey triangles). $* * * \mathrm{p}<0.0001$. Statistical analysis was 
medRxiv preprint doi: https://doi.org/10.1101/2021.03.14.21253039; this version posted March 24, 2021. The copyright holder for this preprint (which was not certified by peer review) is the author/funder, who has granted medRxiv a license to display the preprint in perpetuity.

All rights reserved. No reuse allowed without permission.

performed with Dunn's multiple comparison test. (C) Anti-RBD specific titers in female (black triangles) or male (black squares) HCP. ${ }^{*} \mathrm{p}<0.05$. Statistical analysis was performed with MannWithney test. (D) Anti-RBD specific titers in four defined age groups: 21-30 (circles), 31-40 (squares), 41-50 (triangles), 51-60 (diamonds) at $28 \mathrm{dpv}$. Mean antibody titer for each group is indicated as a red line. ns=not-significant. Statistical analyses were performed with Dunn's multiple comparison test.

In order to perform a longitudinal case control study, we followed a group of 214 individuals and analyzed antibody titers measured at $0 \mathrm{dpv}$ and $14 \mathrm{dpv}$ (Fig. 2A). Of these, 107 completed the vaccination scheme with the second dose (Fig. 2B). The first dose of SPUTNIK V (14 dpv), significantly increased antibody titers both in the group with pre-existing SARS-CoV-2 immunity (basal IgG anti-RBD +) $(\mathrm{p}<0.0001)$, as well as in those without detectable titers at baseline $(\mathrm{p}<0.0001)$ (Fig. 2A). However, the group that was seropositive at baseline achieved a much higher mean antibody titer at $14 \mathrm{dpv}$ (5.4 fold higher) than the control group $(\mathrm{p}<0.0001)$. This highly significant difference suggests that a single dose vaccination in previously exposed individuals elicits a secondary-like immune response, acting essentially as an immune boost. Even in individuals who underwent asymptomatic SARS-CoV-2 infection with basal anti-RBD IgG titers, their antibody response was substantially higher at $14 \mathrm{dpv}$ than those with no basal antibodies (5.5 fold higher, $\mathrm{p}<0.0001)$ (Fig. S1). This asymptomatic group even registered a small but consistently higher mean antibody titer before being vaccinated ( $0 \mathrm{dpv})$ compared to the control group after receiving the first dose $(14 \mathrm{dpv})(\mathrm{p}<0.0001)$ (Fig. S1).

In the subgroup that completed the full vaccination scheme $(28 \mathrm{dpv})$, the second dose of SPUTNIK V elicited higher antibody titers in the group with pre-existing SARS-CoV-2 immunity (2302), compared to the control group (1297) (p <0.05) (Fig. 2B). Notably, a single dose elicited higher antibody titers $(14 \mathrm{dpv}, 1450)$ in the seropositive group than two doses of the 
medRxiv preprint doi: https://doi.org/10.1101/2021.03.14.21253039; this version posted March 24, 2021. The copyright holder for this preprint (which was not certified by peer review) is the author/funder, who has granted medRxiv a license to display the preprint in perpetuity.

All rights reserved. No reuse allowed without permission.

vaccine in the seronegative group $(28 \mathrm{dpv}, 1297)(\mathrm{p}<0.005)$ (Fig 2B). Although this difference was statistically significant, the overall distribution of titers within the seropositive subgroup at $14 \mathrm{dpv}$ appeared asymmetric, with the median significantly below the mean, indicative of a highly heterogeneous response to the vaccine (Fig. 2B). Indeed, if this group is further separated based on titers below or above 400, then the response to the first dose becomes strongly homogeneous in $>400$ subgroup (Fig 2C), strongly suggesting that the anti-RBD IgG titers at baseline have a direct consequence in the overall response to the vaccine. Significant differences in anti-RBD titers were detected after each vaccine dose in both groups, underscoring the general effectiveness of the SPUTNIK V (10).

10 With the aim of determining if there is an optimal window post-SARS-CoV-2 diagnosis in which the SPUTNIK V vaccine stimulates higher antibody titers in seroconverted individuals, we analyzed the effect of days past between diagnosis (in individuals with confirmed positive RTPCR) and vaccination (days post diagnosis, dpd) on anti-RBD IgG titers. Notably, there was no significant difference associated between dpd (at least up to 120 days) and antibody responses to the vaccine (Fig. 3A-C). 
A

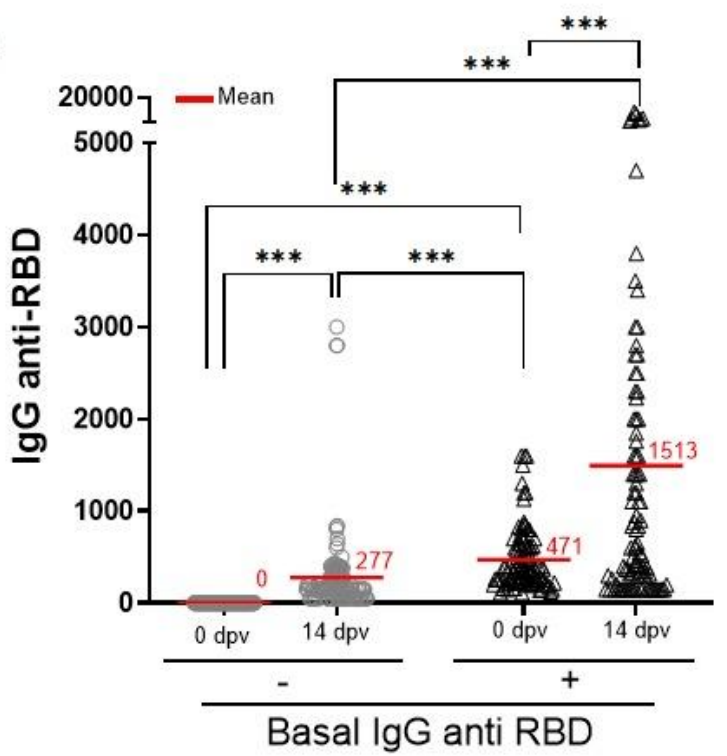

C

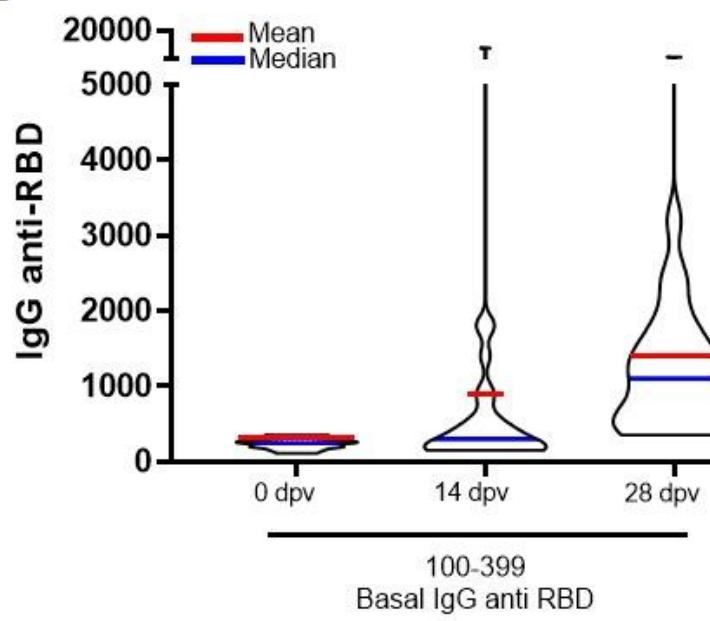

B

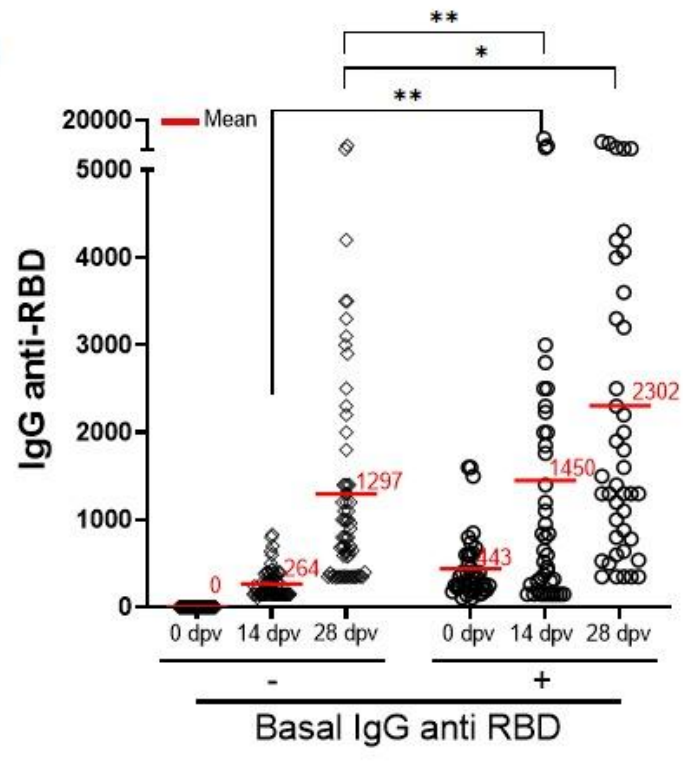

Figure 2. Case and control study of IgG anti-RBD titers upon SPUTNIK V vaccination in individuals with prior SARS-CoV-2 seropositivity compared to uninfected personnel. (A) Longitudinal anti-RBD IgG specific titers, as measured by ELISA, at 0 and $14 \mathrm{dpv}$, in 214 case

controlled individuals. (B) IgG anti-RBD titers in a subgroup of $107 \mathrm{HCP}$ who completed the full vaccination scheme with the second dose $(28 \mathrm{dpv})$. (C) Distribution of previously seroconverted individuals segregated according to basal IgG anti-RBD titers (100-399 and >400) achieved at 0, 14 and $28 \mathrm{dpv}$ in shown as a violin plot. In each panel the mean and the median antibody titer for 
each group are indicated as a red line or a blue line, respectively. *** $\mathrm{p}<0.0001 * * \mathrm{p}<0.005$, ${ }^{*} \mathrm{p}<0.05$. Statistics analysis was performed with Kolmogorov-Smirnov test.

A

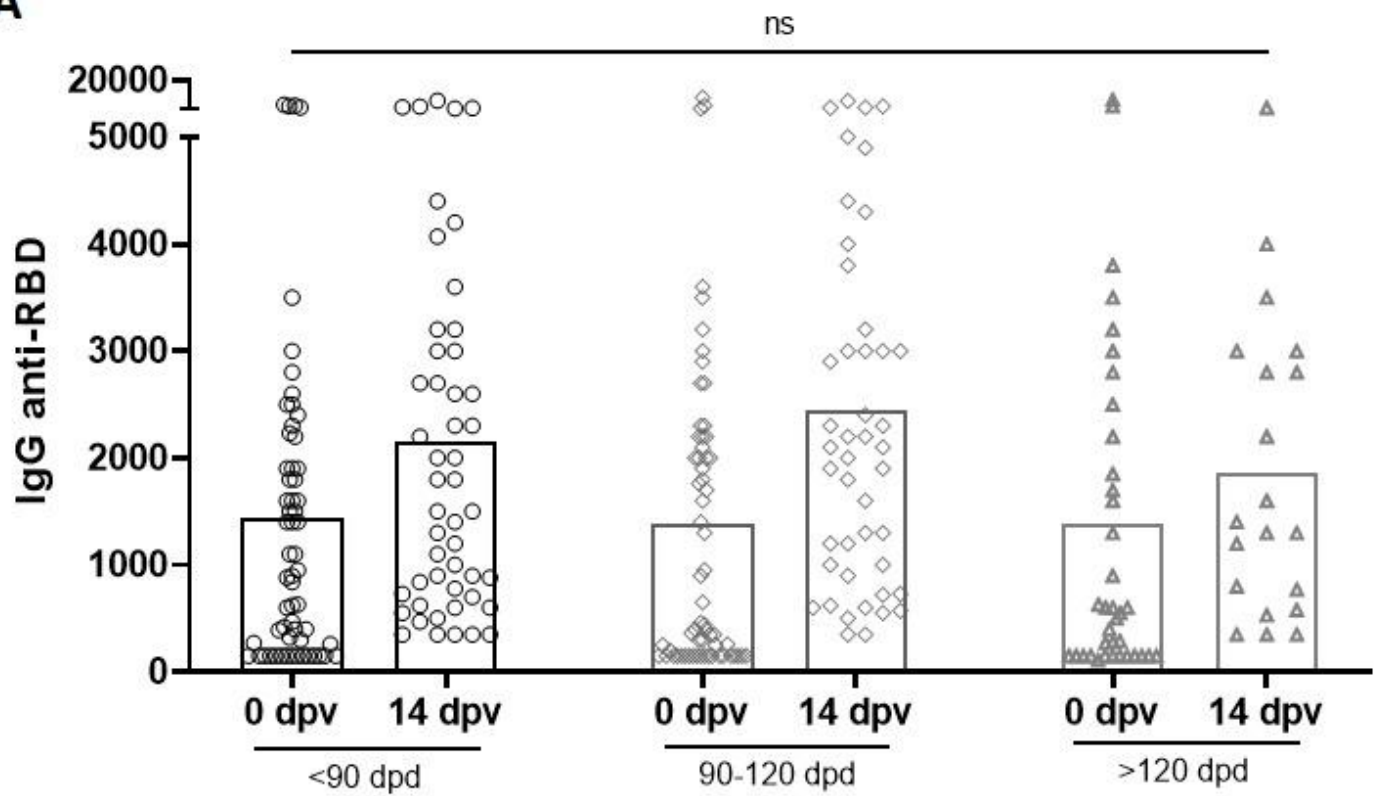

B
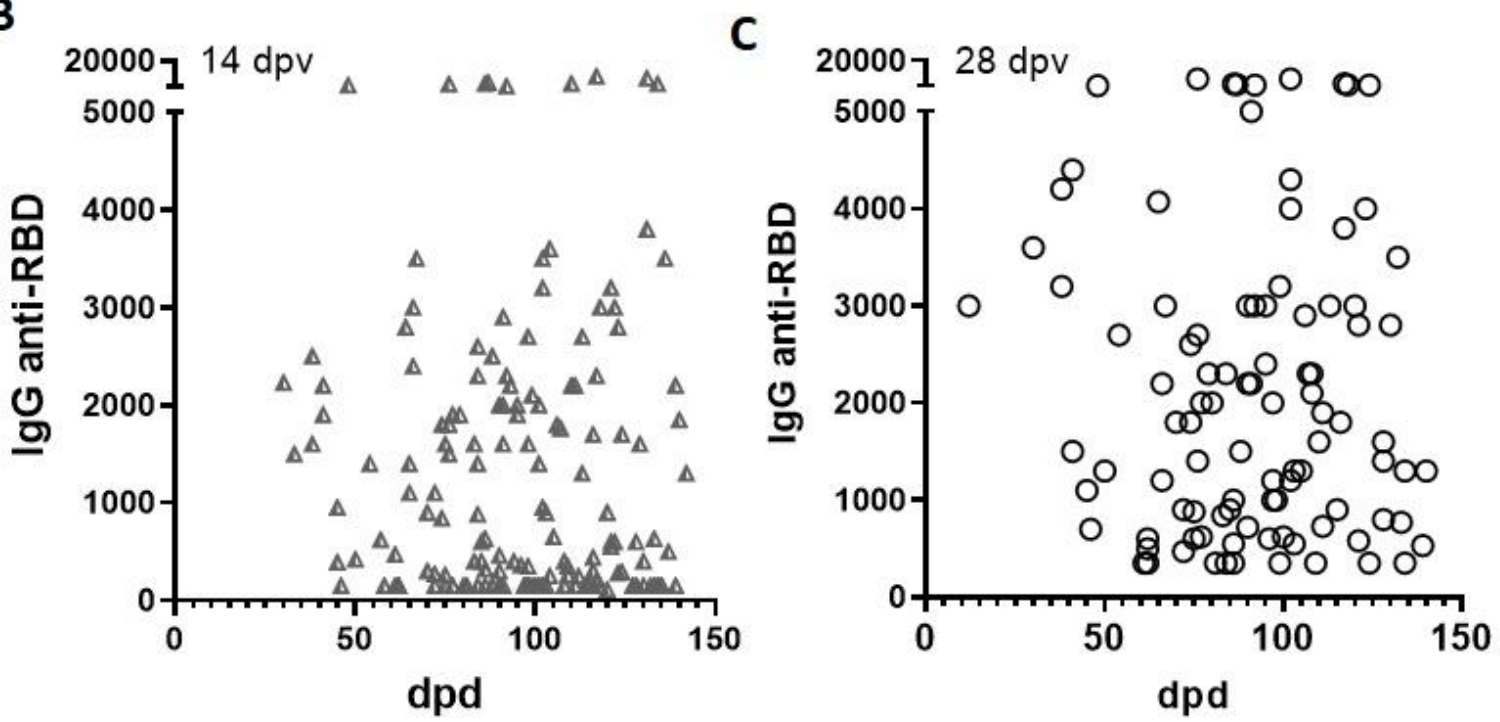

Fig. 3. Effect of time elapsed between diagnosis of SARS-CoV-2 and vaccination with SPUTNIK V on anti-RBD antibody titers. (A) IgG anti-RBD titers triggered by the first (14 
medRxiv preprint doi: https://doi.org/10.1101/2021.03.14.21253039; this version posted March 24, 2021. The copyright holder for this preprint (which was not certified by peer review) is the author/funder, who has granted medRxiv a license to display the preprint in perpetuity.

All rights reserved. No reuse allowed without permission.

dpv) and second (28 dpv) vaccine doses when administered less than 90, between 90-120, and more than 120 days post diagnosis (dpd) of SARS-CoV-2 infection (by RT-PCR or antigen test) ns=not-significant. Statistical analyses were done with Dunn's multiple comparison test (B-C) Correlation between the dpd and IgG anti-RBD titers generated by the first (B) $(r=0.01245$, $\mathrm{p}=0.8770)$ or second dose $(\mathrm{C})$ of the SPUTNIK V vaccine $(\mathrm{r}=-0.03879, \mathrm{p}=0.7045)$. The correlation was analyzed using Pearson Correlation Coefficient.

In a context of limited access to SARS-CoV-2 vaccines, our findings show that in individuals previously exposed to the virus, the first dose of SPUTNIK V elicits a strong humoral immune response comparable or even higher than that reached after two doses in individuals without previous exposure to the virus. Our results suggest that the first dose seems to act as a booster for individuals with detectable anti-SARS-CoV-2 antibody titers (regardless if they were asymptomatic or not), and that screening for SARS-CoV-2 seropositive individuals with titers above 400 among the general population could serve to identify those who might require only one vaccination dose.

\section{References and Notes}

1. P. Zhou et al., A pneumonia outbreak associated with a new coronavirus of probable bat origin. Nature 579, 270-273 (2020).

202 2. M. Lipsitch, N. E. Dean, Understanding COVID-19 vaccine efficacy. Science 370, 763765 (2020).

3. N. G. Davies et al., Estimated transmissibility and impact of SARS-CoV-2 lineage B.1.1.7 in England. Science, (2021).

4. Y. Weisblum et al., Escape from neutralizing antibodies by SARS-CoV-2 spike protein variants. Elife 9, (2020).

5. L. B. Rodda et al., Functional SARS-CoV-2-Specific Immune Memory Persists after Mild COVID-19. Cell 184, 169-183.e117 (2021).

6. G. E. Hartley et al., Rapid generation of durable B cell memory to SARS-CoV-2 spike and nucleocapsid proteins in COVID-19 and convalescence. Sci Immunol 5, (2020). 
medRxiv preprint doi: https://doi.org/10.1101/2021.03.14.21253039; this version posted March 24, 2021. The copyright holder for this preprint

(which was not certified by peer review) is the author/funder, who has granted medRxiv a license to display the preprint in perpetuity.

All rights reserved. No reuse allowed without permission.

7. W. F. Garcia-Beltran et al., COVID-19-neutralizing antibodies predict disease severity and survival. Cell 184, 476-488.e411 (2021).

8. L. Premkumar et al., The receptor binding domain of the viral spike protein is an immunodominant and highly specific target of antibodies in SARS-CoV-2 patients. Sci

Immunol 5, (2020).

9. E. Salazar et al., Convalescent plasma anti-SARS-CoV-2 spike protein ectodomain and receptor binding domain IgG correlate with virus neutralization. J Clin Invest, (2020).

10. D. Y. Logunov et al., Safety and efficacy of an rAd26 and rAd5 vector-based heterologous prime-boost COVID-19 vaccine: an interim analysis of a randomised controlled phase 3 trial in Russia. Lancet, (2021).

\section{Acknowledgments:}

We thank Mr. Claude Burgio (SkyBio LLC), Ing. Luis Rocha, Ing. Marina Gandur, Dr. Christian Jaroszewski, Dr. María de los Angeles Peral de Bruno and Lic. Lorena Naidicz. We thank Aaron

Schmidt for providing valuable reagents.

Funding: This work was funded by

Ministerio de Salud Pública de Tucumán (REC, RTG, SIC, DP, EVP, MAL, PA, MA, EMdMV, AS, CLA, CMG, SBS, DH, SAN, CLL, DC, IF, GP, RNC)

Argentinean Research Council-CONICET grants PIP 722 and 806 (RNC, CMG)

Argentinean Research Agency grants MINCYT PICT-2018-3379 and PICT2018-02989 (DP, SBS)

Tucuman National University grants (PIUNT-UNT D644/1 and D624 (CLA, CMG)

Fundación Florencio Fiorini (DP)

\section{Author contributions:}

25 Conceptualization: RECH, RCH, GP, GA, CLL

Methodology: RHTG, SIC, DP, EVP 
medRxiv preprint doi: https://doi.org/10.1101/2021.03.14.21253039; this version posted March 24, 2021. The copyright holder for this preprint (which was not certified by peer review) is the author/funder, who has granted medRxiv a license to display the preprint in perpetuity.

All rights reserved. No reuse allowed without permission.

Investigation: PA, MA, EMdMV, AS, CLA, SBS, RHTG, DH, SN, CMG

Visualization: RCH, GP, GA, GM, RM

Funding acquisition: RECH, RCH, DP, SBS, CA

Project administration: RCH, MAL

Supervision: RCH, SC, EVP, DC, IF

Writing - original draft: DP, RCH, GP, RHTG, SC

Writing - review \& editing: GM, RM, GA, RCH, DP, RHTG, SC, EVP

\section{Competing interests:}

Authors declare no competing interests. 

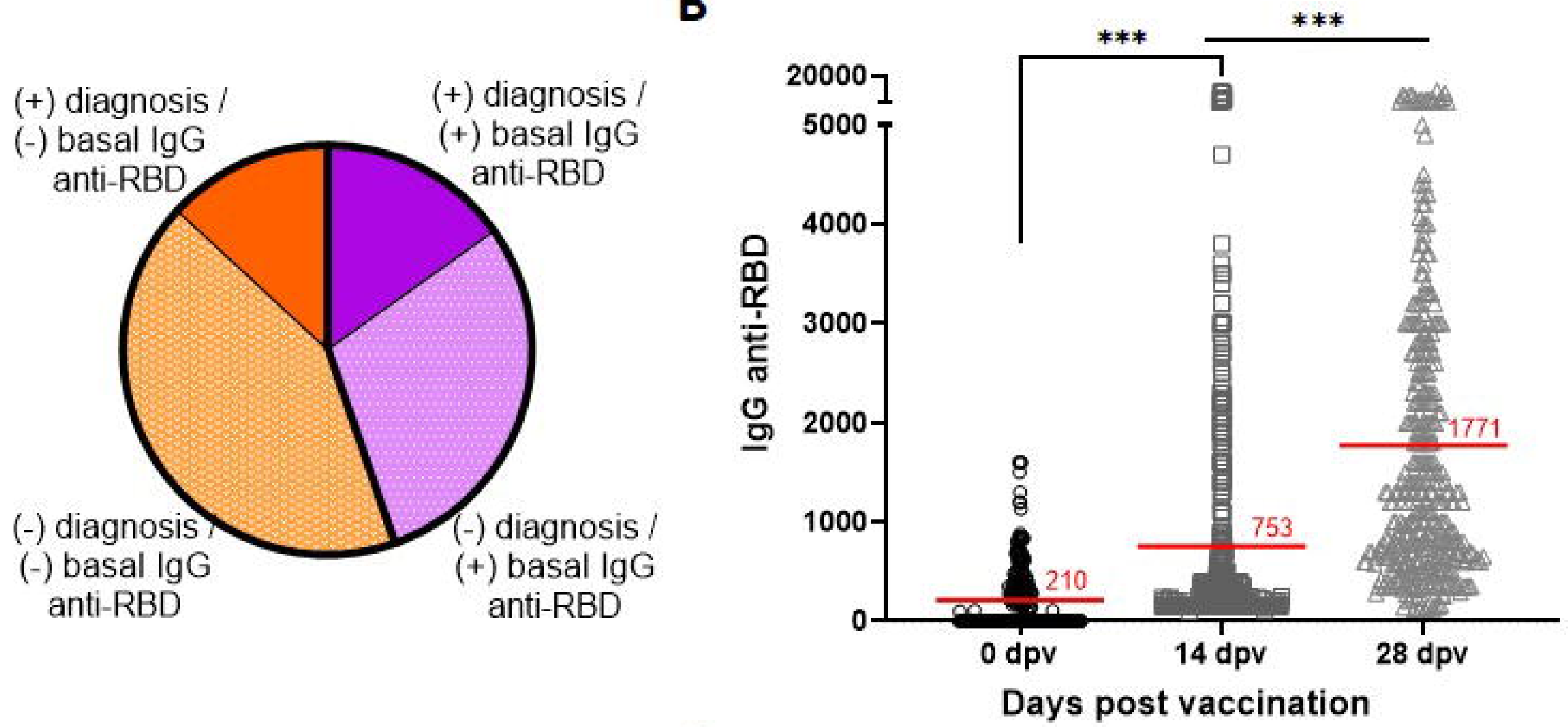

C

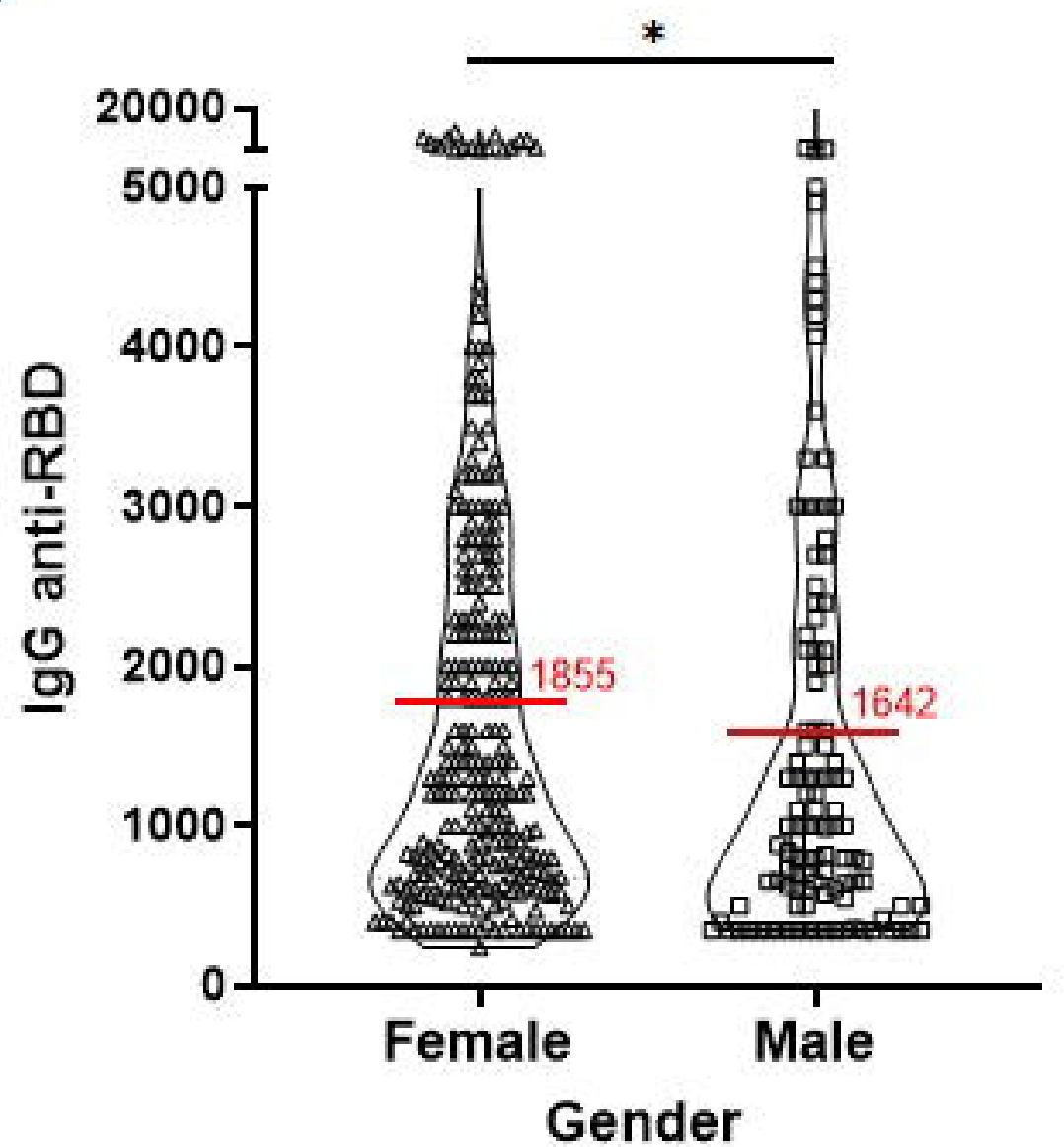

D

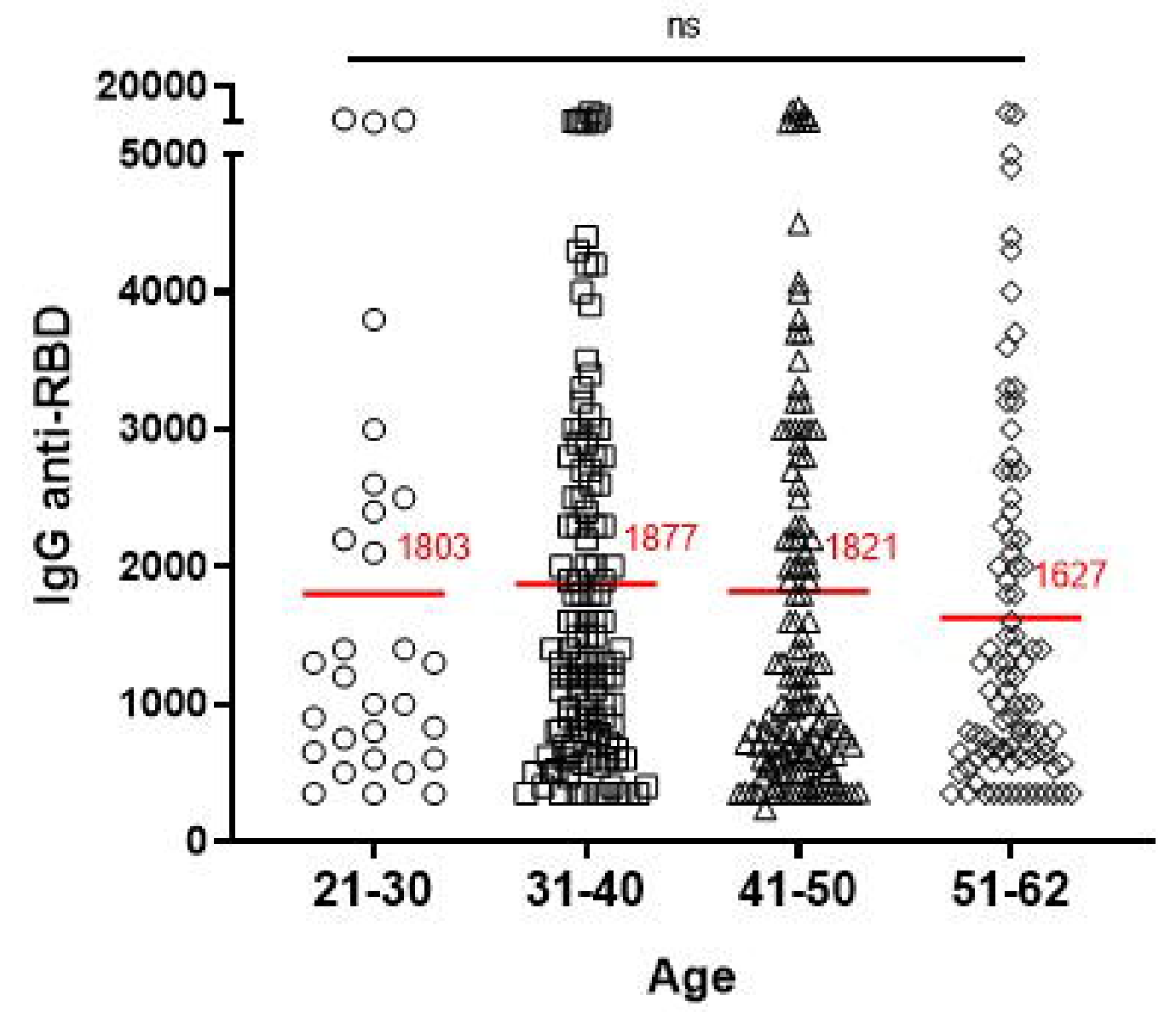


A

B

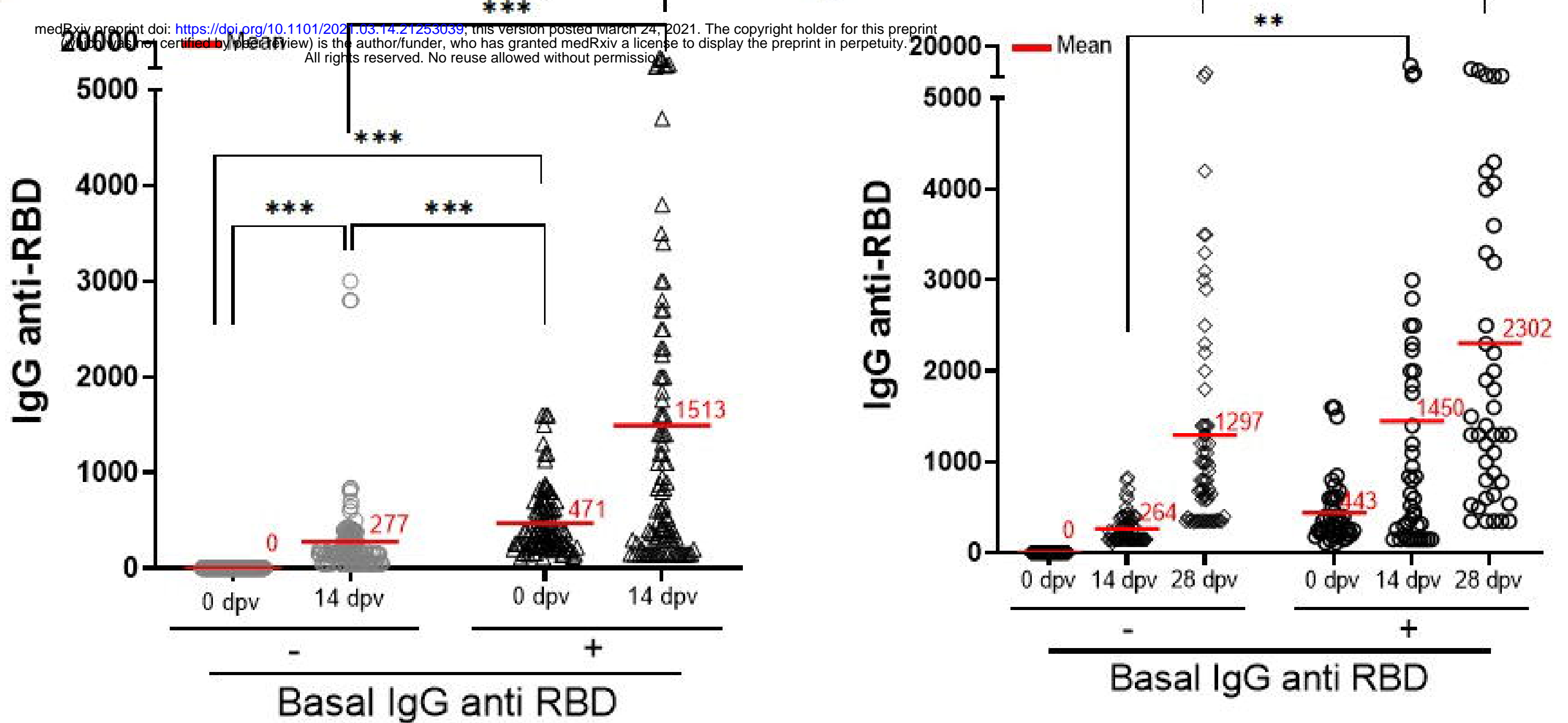

C

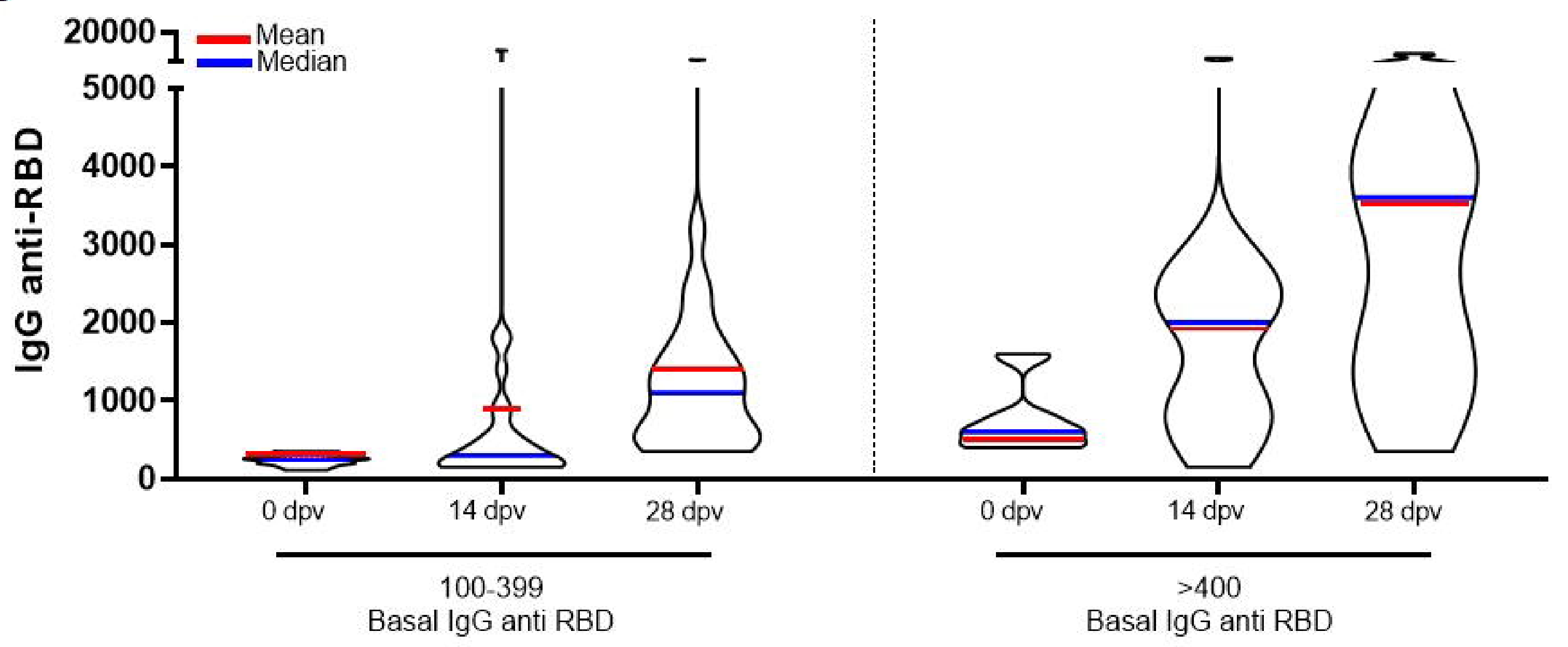




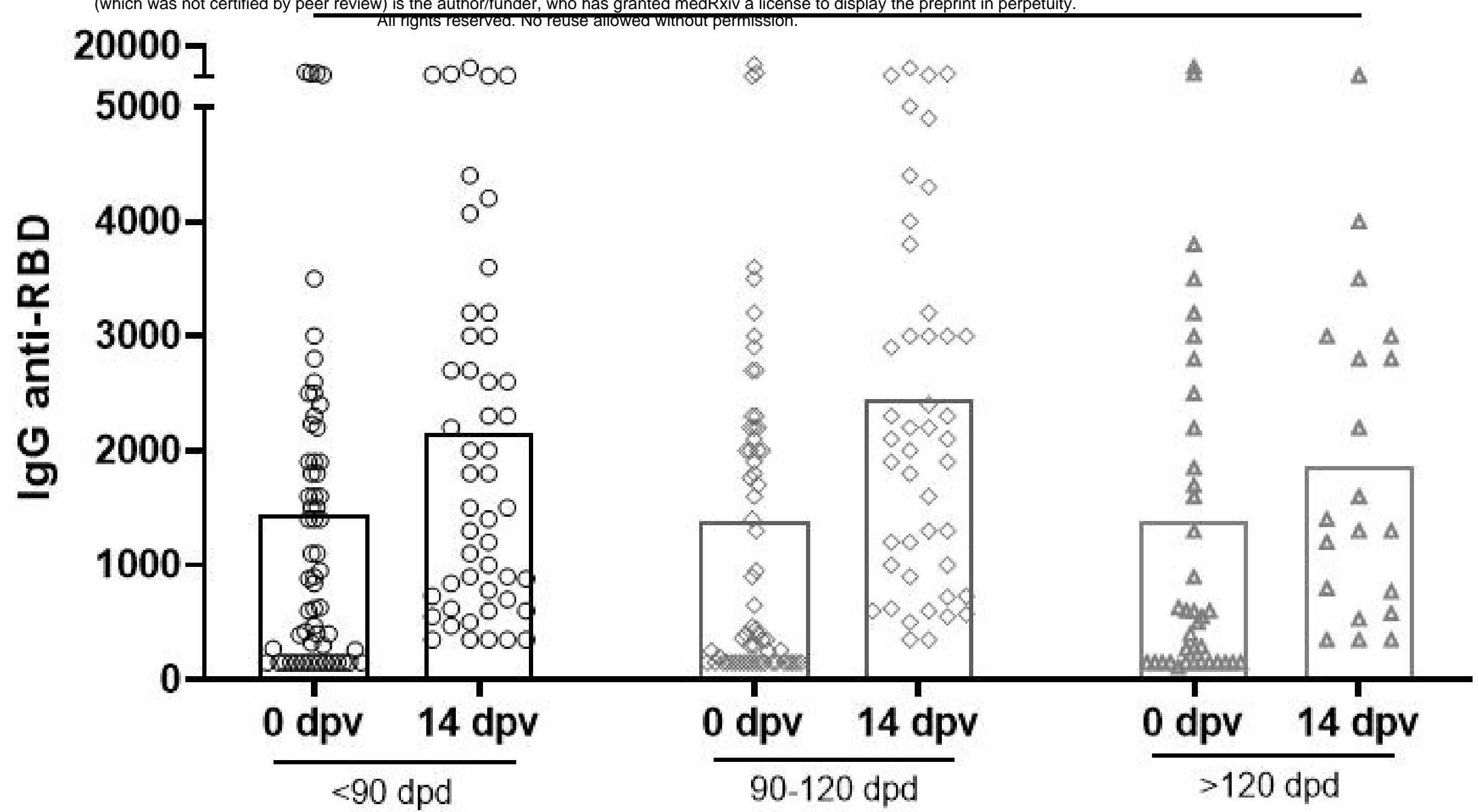

B

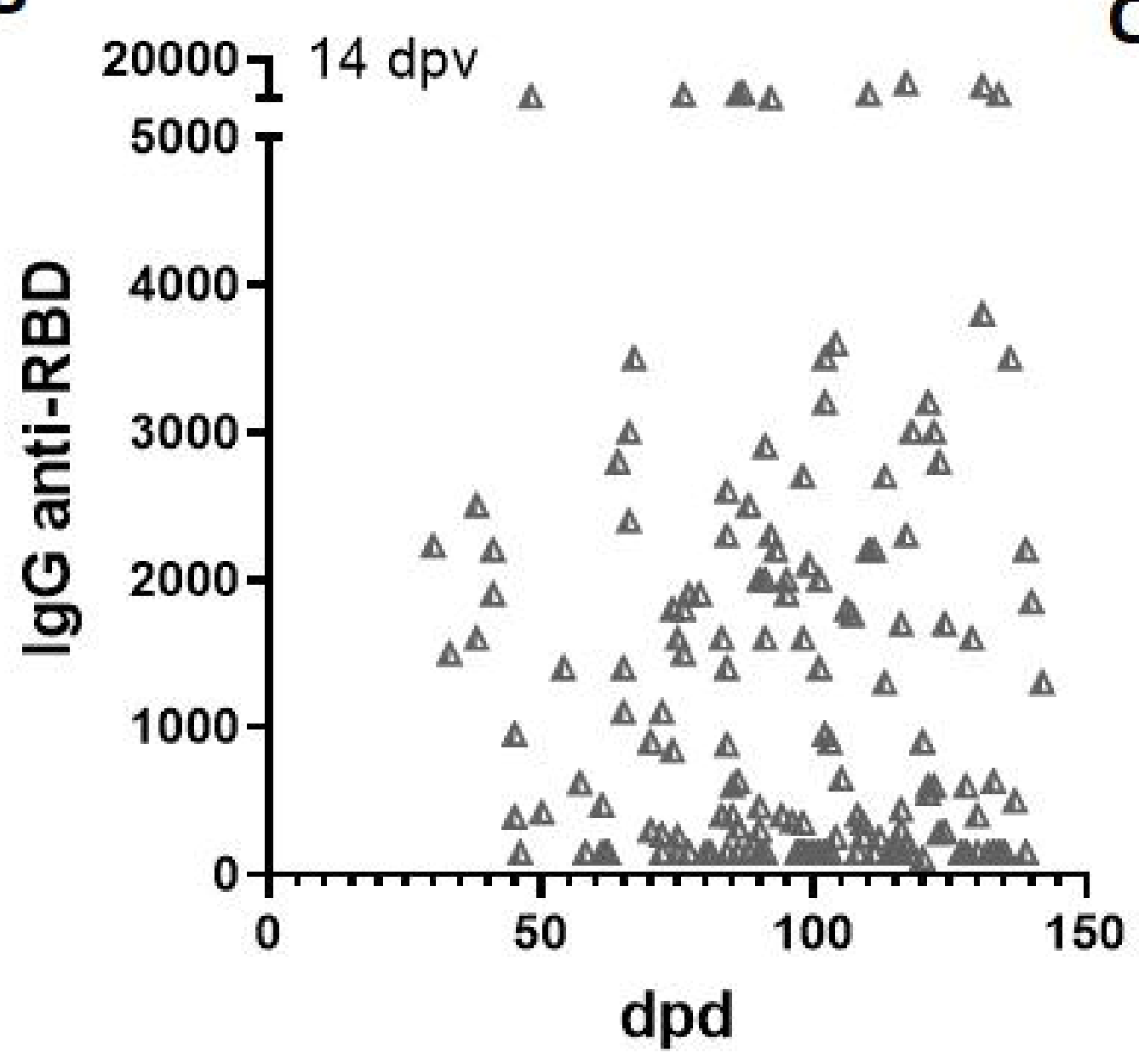

${ }^{20000} \mathrm{I}^{28 \mathrm{dpv}} \circ \mathrm{O}_{0} \circ \infty$

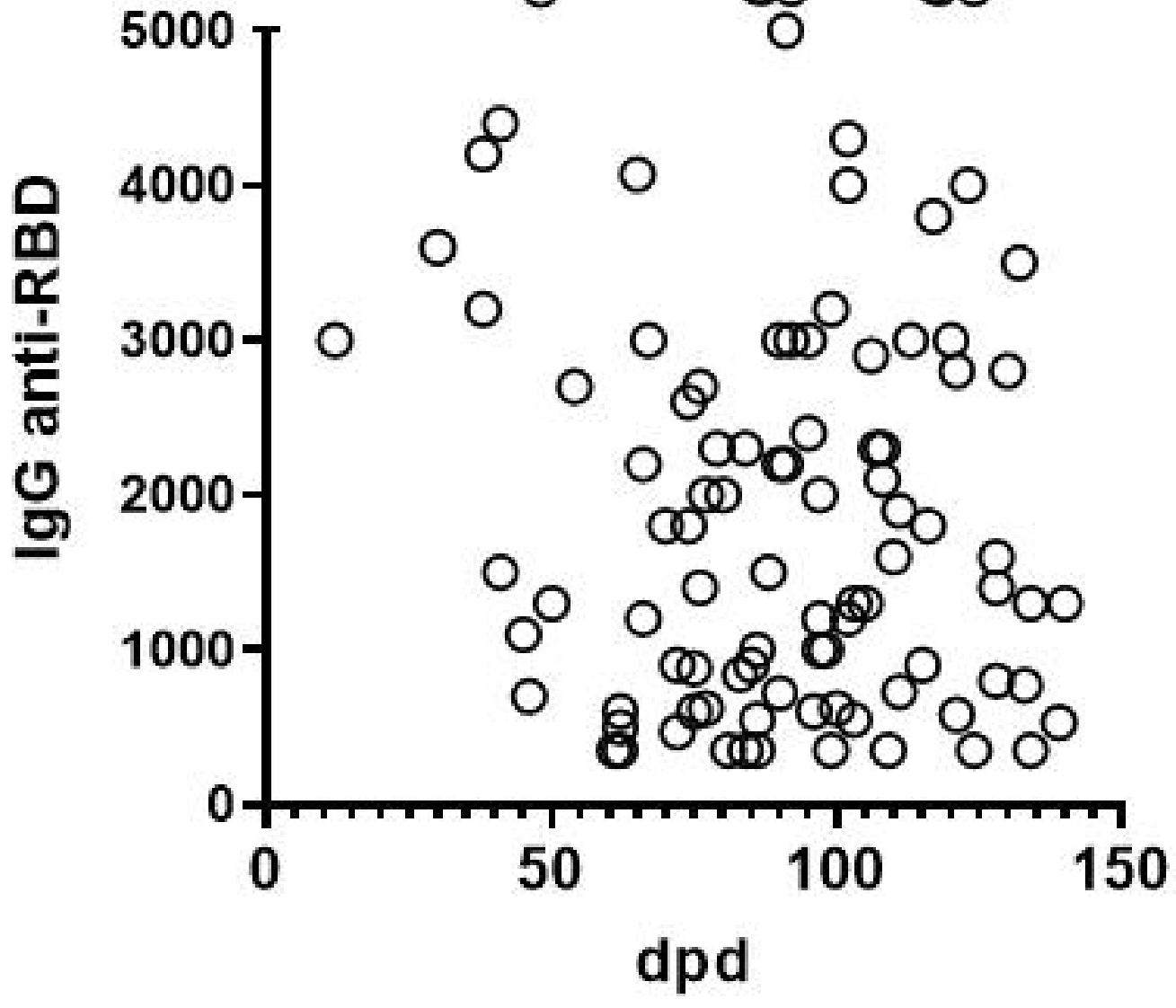

